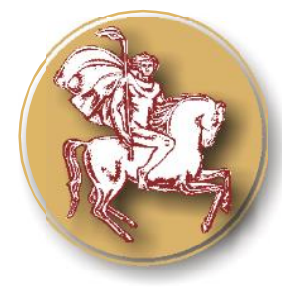

Trakia Journal of Sciences, No 4, pp 285-293, 2021

Copyright (C) 2021 Trakia University

Available online at:

http://www.uni-sz.bg

ISSN 1313-3551 (online)

doi:10.15547/tjs.2021.04.001

\title{
MOTIVATION OF ENGLISH-SPEAKING STUDENTS TO STUDY VETERINARY MEDICINE AT TRAKIA UNIVERSITY
}

\author{
G. Balieva* \\ Department of Hygiene, Technology and Control of Food Products of Animal Origin, Veterinary \\ Legislation and Management, Faculty of Veterinary Medicine, Trakia University, Stara Zagora
}

\begin{abstract}
International migration of tertiary students is a global trend which gives higher education institutions a strong incentive for quality development, service improvement and competitiveness. Research has shown that the attractiveness of educational services is dependent on factors with national-international characteristics and factors based on the demographic profile of students. PURPOSE: The aim of this study was to investigate the motivators which influence students` personal attitudes towards studying veterinary medicine in English at Trakia University, Bulgaria. METHODS: A five-year survey among 93 first-year English speaking students in veterinary medicine at Trakia university was conducted through anonymous written questionnaire between 2015 and 2019. Data obtained were statistically processed. RESULTS: Significant differences were found for several factors which drove respondents' motivation in choosing their master's degree. Among these factors were gender, parents` occupational profile, country of origin, tuition fees, as well as existing experience in breeding, interaction with animals and volunteering in the veterinary field. The most preferred source of information for veterinary medicine programmes and universities appeared to be recommendations from respondents` relatives, friends and mentors. CONCLUSION: Understanding the motivation drivers of English-speaking veterinary students will help the improvement of the educational service offered and the competitiveness of the institution internationally.
\end{abstract}

Key words: veterinary students, international mobility, higher education, demographics

\section{INTRODUCTION}

The area of higher education is continuously developing in order to respond adequately to the needs of the changing labour market. Regarding the trend of globalization of services and goods, higher education institutions have started implementation of strategies and policies to attract more international students from neighbouring countries and further afield (1), thus becoming more competitive and sustainable. Traditionally, universities from Western Europe and North America are well recognized in the

\footnotetext{
*Correspondence to: Gergana Nikolova Balieva, Department of Hygiene, Technology and Control of Food Products of Animal Origin, Veterinary Legislation and Management, Faculty of Veterinary Medicine, Trakia University, Stara Zagora 6000, Bulgaria; email: gnikolova.vet@gmail.com
}

international education area, offering profitable and competitive educational services $(2,3)$. At the same time, new competitors have appeared on the global market trying to position themselves as "new" higher education hubs (4-8). The intensified tertiary student mobility worldwide is therefore well documented with the increase from 0.8 mln students in 1975 to $3.3 \mathrm{mln}$ in 2008 (3), reaching more than $5 \mathrm{mln}$ or about $2 \%$ of all global tertiary enrolments in 2016-2017 $(9,10)$.

The key players on the European market for inbound international students` mobility are reported to have education organizations with a long tradition in teaching and research and high credibility for their academic standards (3) with increased attractiveness for students from other regions of the world (11). At the same time, smaller European countries have made efforts to 
prevent an outbound mobility through implementation of impressive marketing strategies to target potential international students $(1,12,13)$. Research studies have identified that the most important factors that affect student mobility could be divided into two main groups factors with national-international characteristics (financial aspects, immigration policy and perceived academic superiority of the institutions in the host countries) and factors based on the demographic profile of students (14-18).

In the field of veterinary medicine investigation of motives and barriers for the internationalization of higher education has confirmed the leading role of economic, geographic, cultural and social factors in students` decision-making $(14,19,20)$. For Bulgaria, the factors which determine the attractiveness of veterinary medicine to students have been studied for decades $(24,25)$, focusing on regionalization at the national level. Regarding international students, data showed that countries that joined the EU most recently, i.e. Croatia, Bulgaria, and Romania, are represented in the tertiary international mobility with shares of mobile students below 5\% (26).

\section{PURPOSE OF THE STUDY}

The present study is aimed at identifying the most important factors that could affect foreign students` motivation to study veterinary medicine in the English-language programme at Trakia University, Bulgaria.

\section{MATERIALS AND METHODS}

The study was carried out under the form of an anonymous written questionnaire among English-speaking veterinary students at Trakia University - Stara Zagora (TrU) $(\mathrm{n}=93)$ for a five-year period, starting from 2015/2016 till $2019 / 2020$ academic year. At the beginning of the winter semester each student enrolled in the elective course of History of Veterinary Medicine in English was asked for his/her willingness to participate in the survey and students with positive answer were given a paper questionnaire to fill it in anonymity and return it to the author.

The questions were distributed in two sections. Briefly, the first section (questions 1-6) contained questions on the participant's demographic data. The second section (questions
BALIEVA G.

7-9) contained open-ended questions that aimed at determining the participants' motivation to study veterinary medicine in general and reasons to choose Trakia University as an educational institution.

Data received were statistically processed (Statistica v. 7 software, StatSoft, Inc.). The study parametres were analyzed through descriptive statistics (frequency distribution tables), correlation analysis (Pearson correlation coefficient) and Student's t-test (t-test for independent samples). A two-sided $\mathrm{p}<0.05$ was considered significant. The results afterwards were presented on diagrams (Excel, Windows $10)$.

\section{RESULTS}

The summarized results regarding the demographic profile of the English-speaking students at the Faculty of Veterinary Medicine (FVM) are presented in Table 1. The majority of participants in the study were women, making up $60.67 \%$ of the total, compared to $39.33 \%$ for men. The students` distribution by age was uneven, with the main share of them falling into the group between 18-24 years old $(90.80 \%)$, represented by young people who had just completed their high education or college. The remaining $10 \%$ of respondents were divided into age categories after 25, 31 and 41 years, represented by persons who already had a university education and professional qualification (nurse, dentistry, etc.), but wished to change profession or to upgrade formally or informally acquired experience in the field of veterinary medicine and other health specialties. (Table 1)

The analysis of the multinational profile of the respondents showed that the highest relative share of $62.50 \%$ got the citizens of countries from the Balkans and the region, mainly Greece, Turkey, Cyprus, located in territorial proximity to Bulgaria. The share of students from other countries within Europe was smaller - 31.82\%, mainly residents of Great Britain and Ireland. Although poorly represented, the relative share of $5.68 \%$ of students from countries from other continents could be interpreted as a positive assessment of the position of the Faculty in the international higher education area. 
Table 1. Respondents`demographic profile*

\begin{tabular}{|c|c|c|}
\hline Respondents`demographics & Count & Percentage \\
\hline \multicolumn{3}{|c|}{ Academic year admission /Mean 3,44; Std. Dev. $\pm 1,23 /$} \\
\hline $2015 / 2016$ & 9 & 9.68 \\
\hline $2016 / 2017$ & 9 & 9.68 \\
\hline $2017 / 2018$ & 29 & 31.18 \\
\hline $2018 / 2019$ & 24 & 25.81 \\
\hline $2019 / 2020$ & 22 & 23.65 \\
\hline \multicolumn{3}{|l|}{ Gender /Mean 1,39; Std. Dev. $\pm 0,49 /$} \\
\hline Female & 54 & 60.67 \\
\hline Male & 35 & 39.33 \\
\hline \multicolumn{3}{|l|}{ Age (years) /Mean 1,15; Std. Dev. $\pm 0,54 /$} \\
\hline $18-24$ & 79 & 90.80 \\
\hline $25-30$ & 5 & 5.75 \\
\hline $31-40$ & 1 & 1.15 \\
\hline $41+$ & 2 & 2.30 \\
\hline \multicolumn{3}{|l|}{ Country of origin /Mean 1,43; Std. Dev. $\pm 0,60 /$} \\
\hline Countries from/close to the Balkan peninsula & 55 & 62.5 \\
\hline Countries in Europe & 28 & 31.82 \\
\hline Countries outside Europe & 5 & 5.68 \\
\hline \multicolumn{3}{|c|}{ Parents`professional occupation /Mean 3,54; Std. Dev. $\pm 0,95 /$} \\
\hline Veterinary Medicine & 8 & 8.60 \\
\hline Husbandry & 6 & 6.45 \\
\hline Agriculture & 6 & 6.45 \\
\hline Other professional spheres & 73 & 78.5 \\
\hline \multicolumn{3}{|l|}{ Education /Mean 1,47; Std. Dev. $\pm 0,77 /$} \\
\hline High school & 65 & 69.90 \\
\hline College & 12 & 12.90 \\
\hline Higher & 16 & 17.20 \\
\hline
\end{tabular}

*Values may not total $100 \%$ for each variable because of nonresponding and rounding of values

Parents` professional employment as a factor was found to influence the choice of the undergraduates from the English-language programme. Results showed that respondents whose parents were employed in the field of veterinary medicine and agricultural sciences represented $21.50 \%$ in total. Statistically significant differences were found in favour of the group of students whose parents were employed in agriculture and those who chose to study veterinary medicine at the university level at FVM as a prestigious faculty $(\mathrm{t}$ [178] = $3.5931 ; \mathrm{p}=0.0000)$.

The indicator "previous experience with animals" was studied to determine the impact of long-term relationships between humans and animals on the formation of career attitudes in the field of veterinary medicine. The survey showed that $42.40 \%$ of respondents, who chose to study in the 
English language programme, actively cared for pets, among which traditional pets like dogs and cats, ornamental animals, fish, but also horses, pigs, chickens were kept as animals for a company at home. The share of undergraduates with an opportunity to interact directly with animals within a veterinary working environment due to parents ' professional occupation was very low $-1.08 \%$. At the same time, $9.78 \%$ of the respondents had gained practical formal or
BALIEVA G.

informal experience with animals as a result of work or experience in veterinary practices, farms, shelters, parks (including volunteering). This experience correlated positively with the country of origin of the students $(R=0.3779 ; p<0.05)$. At the same time country of origin was found also to correlate with the indicator "reasons for choosing veterinary medicine" $(\mathrm{R}=0.2388 ; \mathrm{p}<0.05)$. (Figure 1)

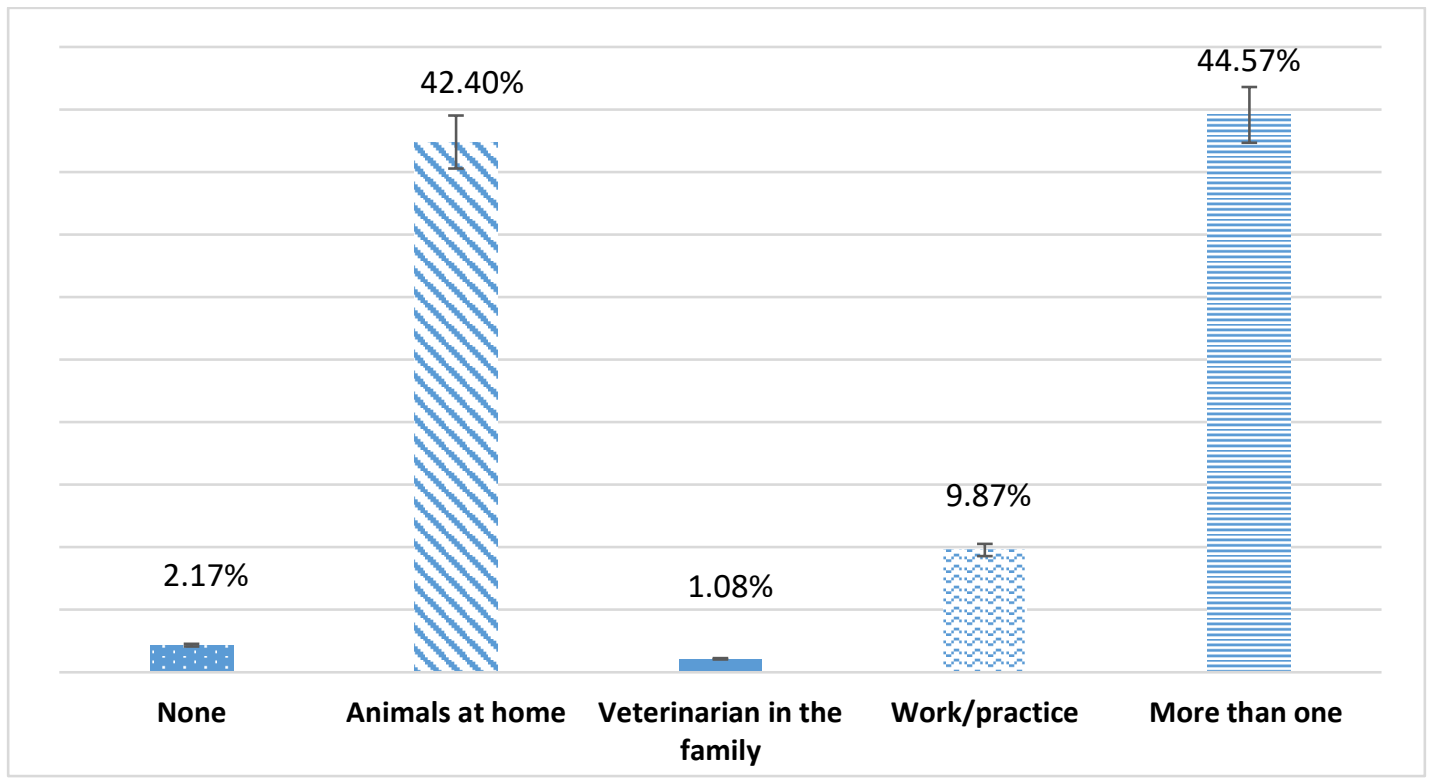

Figure 1. Previous experience influencing the respondents` intention to study veterinary medicine

The largest share of $44.57 \%$ got the respondents, who indicated that their experience with animals was based on many forms of interactions, grouping some of the already mentioned answers - keeping pets and caring for animals at veterinary practices, shelters, conservation and nature parks, etc. during internships or volunteer programmes. In addition to the demographic indicators involved in the formation of attitudes towards veterinary education, the study found that other factors played an important role among Englishspeaking students, such as the availability of sufficient, accessible, and up-to-date information about educational institutions. Among the information channels used by our respondents in the process of searching for veterinary medicine programmes outside their home countries, most preferred appeared to be information shared by their relatives and friends $-53.85 \%$. A clear and statistically significant difference was established between the group of English-speaking students who in their previous education were interns or volunteers in veterinary and livestock facilities and the group of respondents who trusted the advice of friends in choosing a faculty, incl. contacts from their internships $(\mathrm{t}[181]=10.8519$; $\mathrm{p}=0.0000$ ). (Figure 2)

As another preferred means to search for and compare tuition opportunities in veterinary medicine $39.56 \%$ of respondents indicated websites and online advertising products, which offered timely updated, accurate and detailed information on both the educational services and logistics, social and cultural environment on campus and the country. The least preferred information source (pointed out by $6.59 \%$ of the foreign undergraduates) remained the agencies and specialized offices for recruiting students, which served as a link between the candidates and the educational institution and supported the overall process of application and enrolment. The 
effectiveness of the information channels used was confirmed statistically, as there were significant differences in favour of the group of respondents accepted for training in the
BALIEVA G.

2018/2019 academic year and the candidates who used Internet sources for their choice of FVM at $\operatorname{TrU}(\mathrm{t}[182]=12.3866 ; \mathrm{p}=0.0000)$.

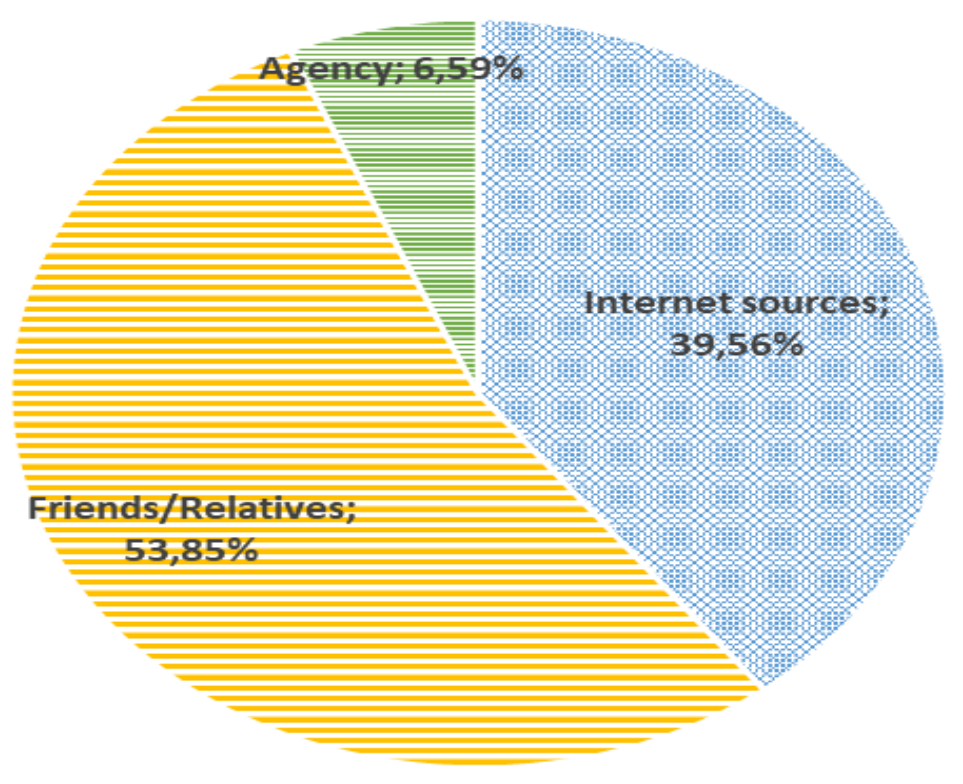

Figure 2. Preferred information channels by English-speaking veterinary students

The study showed that the psychological attitudes of foreign students to study at the Faculty of Veterinary Medicine at Trakia University in Bulgaria were formed by a complex of factors, among which highly important appeared to be cost of living, proximity to their homeland and international recognition of the institution. The prestige of the FVM and its EAEVE status were leading motives for $29.89 \%$ of the respondents. The undergraduates` choice was also influenced by the low tuition fee compared to other European universities, indicated by $12.64 \%$ of the respondents, as well as the proximity of Bulgaria to the country of origin for $10.34 \%$ of Englishspeaking students (mainly Greece, Turkey and Cyprus citizens). (Figure 3)

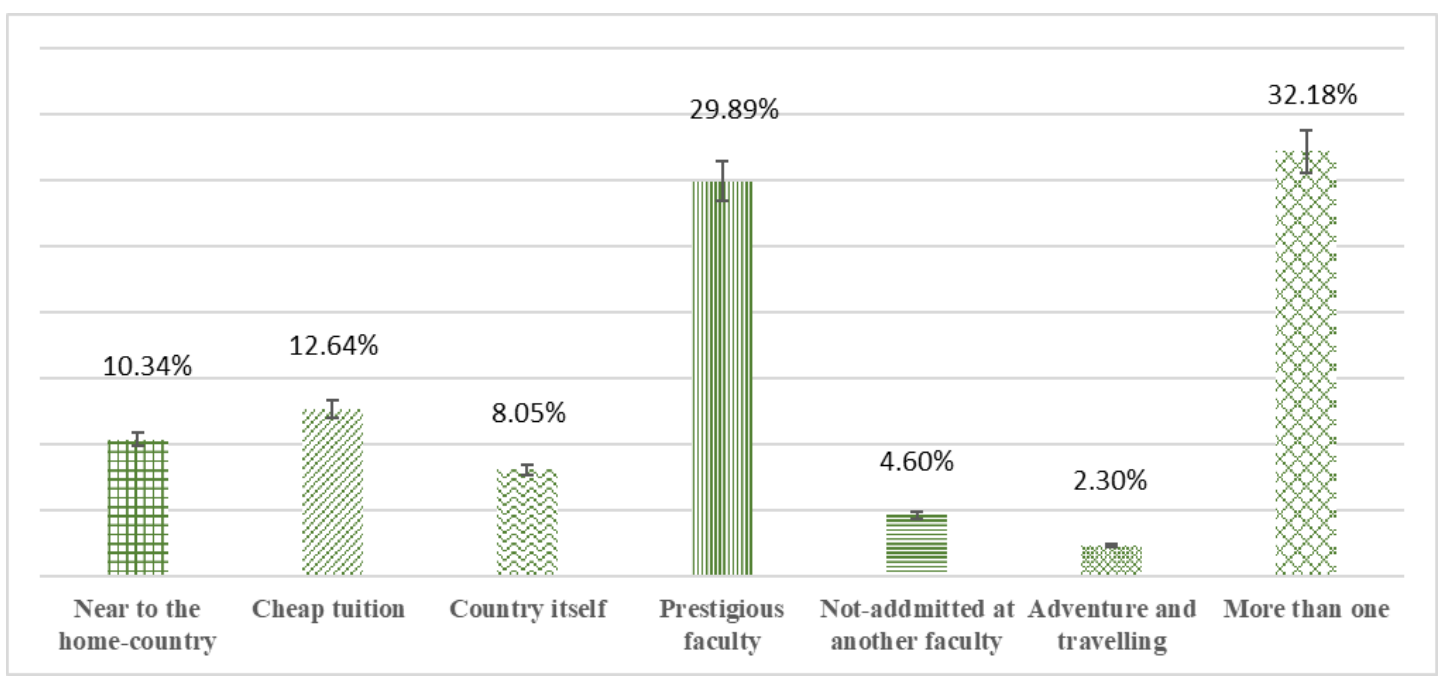

Figure 3. Motivation drivers of English-speaking students to study at FVM- TrU 
Significant differences were found in favour of the female students who indicated as a motive for their choice the high public prestige of the institution ( $\mathrm{t}[174]=-13.1753 ; \mathrm{p}=0.0000)$, recognizing the FVM at $\mathrm{TrU}$ as an established faculty with international traditions and achievements in veterinary science and practice.

\section{DISCUSSION}

The internationalization of higher education is a global process which impact strengthens the competitiveness of the countries, cooperation and funding in specific scientific areas (21-23). For Bulgaria, this process in the field of veterinary medicine intensified with the enrollment of English-speaking students at Trakia University in 2015 , thus forming a flow of foreign students with different backgrounds and motivations to study veterinary medicine. It appeared that the female undergraduates represented the majority of the respondents $(60.67 \%)$ which corresponded with the global trend of feminization of the profession $(14,20,27,28)$. Female veterinary students were found to hold more positive attitudes towards animals $(29,30)$ which predetermined their choice of profession, although for some universities differences between males and females were not identified in the willingness to pursue a veterinary career (31). International migration in higher education was defined by Collins (32) as a social and geographic process. Research studies argued that the education mobility of degree-seeking students could be investigated at global and regional geographic scales $(33,34)$ with diversification of the study-migration pathway and students considering universities outside the traditional western host countries (5-6). Furthermore, it appeared that rather than truly global, the distribution of international students was macro regional (35), which for the European universities meant that applicants come mainly from the continent (36). Regarding Europe, data showed that the inbound internationally mobile students were estimated to reach 2107 298, 68 in 2017, from which 13746 or $0.65 \%$ foreign students had chosen Bulgaria for their university degree (37). The present study found that the majority of the respondents $(62.5 \%)$ come from countries within or close to the Balkan region (as Greece, Turkey, Cyprus), in confirmation of the global flow of tertiary-level international students for Bulgaria
BALIEVA G. (37). In consistence with these findings other universities also attracted a high proportion of international students from neighboring countries $(8,38)$.

Among the social factors which influence decision-making process of international applicants for higher education appeared to be the occupational profile of their parents. Our results showed that the parents of $21.50 \%$ of the respondents in total were employed in the field of veterinary medicine and agricultural sciences, which could be interpreted as a motive for continuing family business or strengthening of existing human-animal relationships. Similar studies had found that for undergraduates at nine European veterinary universities $6 \%$ of the parents were veterinarians and $15 \%$ were farmers (39). At the same time, the exposure to a veterinary role model and the occupational image of the veterinarian appeared to be major factors for choosing a veterinary career (40-42). Additionally, animal ownership and growing up with animals were also found to play a role in the formation of decision-making for choosing veterinary medicine $(31,43)$, in correspondence with our results for $42.40 \%$ of the foreign students who had grown up with or cared for animals at home. For another $9.78 \%$ of the respondents, regarding the established education system in their country and required participation in internships or practices and voluntary programmes, acquired veterinary experience was also confirmed to build lasting positive attitudes towards animals in general and to participate in early career guidance of young people, reported also by Tomlin et al. (41), Amass et al. (31) and Lazarova (44).

Regarding the information channels, most trusted appeared to be the recommendations from relatives or friends of the respondents $(53.85 \%)$, which other studies found to be shared based on their own observations of the quality of teaching (45). Similar results were obtained for Russia as Orlova \& Zavodyan (46) reported that $60 \%$ of the foreign citizens chose to study at Russian universities after recommendations of their relatives. It was argued that students opinion on the educational institution was formed also through marketing activities developing a distinctive image of the institution $(47,48)$. In these activities, we could include available 
information on the Internet, recruitment agencies and advertising on the website of the FVM and other international informative sites. Examples of the successful educational marketing at University level gave Andrews (27), British Veterinary Association (49-51), and Urbanovic et al. (1) who reported about launching career and education services and fairs.

Cubillo et al. (52) argued that the intention of the international students to choose a certain educational service was formed by a set of factors: personal reasons; the effect of country image; institution image; and evaluation of the study programme. Regarding the image of the educational institution research studies showed that prestigious international university ranking with high quality of education appeared to be among the leading motives for degree-seeking foreign citizens $(12,46,53)$. The international recognition and prestige was found to be of a significant difference for the female Englishspeaking students in our survey $(\mathrm{p}<0.05)$. However, an important factor for considering higher education in the host country was argued to be the low tuition $\operatorname{cost}(12,17,54)$ as for typical veterinary students studying veterinary medicine was considered financially worthwhile (18), measuring the expected debts for education and expected outcomes after graduation $(40,55)$. The financial cost of education was pointed out as a decisive factor by $12.64 \%$ of our respondents.

\section{CONCLUSION}

It could be concluded that international inbound mobility at Trakia University, Bulgaria corresponded with the trends of globalization and regionalization in higher education institutions

worldwide. Meanwhile, evidence for feminization was obtained for the Englishspeaking veterinary students, in line with the global trends for feminization of the veterinary profession in general.

The international degree-seeking students were attracted to study veterinary medicine in Bulgaria by a set of heterogenous factors. Among them significantly important appeared to be students` demographics, previous experience in the sphere and the image of the educational institution. These facts could be investigated further in order to improve the marketing activities for the educational service offered and thus to increase
BALIEVA G.

the competitiveness of the Faculty of Veterinary Medicine at Trakia University, Bulgaria at the international level.

\section{ACKNOWLEDGMENTS}

The author would like to thank all Englishspeaking veterinary students at Trakia University who filled in the questionnaire. This research received no external funding.

\section{REFERENCES}

1. Urbanovič J., Wilkins S., Huisman J., Issues and challenges for small countries in attracting and hosting international students: the case of Lithuania, Studies in Higher Education, 41(3), 491-507, 2014.

2. Baláž V., Williams A.M., Been there, done that': International student migration and human capital transfers from the UK to Slovakia, Population, Space and Place 10(3): 217-237, 2004.

3. Rachaniotis N., Kotsi F., Agiomirgianakis, G., Internationalization in Tertiary Education: Intra-European Students Mobility. Journal of Economic Integration, 28(3), 457-481, 2013.

4. Olds K., Global assemblage: Singapore, foreign universities, and the construction of a 'global education hub, World Development 35(6): 959-975, 2007.

5. Knight J., Education Hubs: A Fad, a Brand, an Innovation? J Stud Int Educ, 15(3), 221-240, 2011.

6. Mok K.H., Yu K.M., The quest for regional education hub status and transnational higher education: Challenges for managing human capital in Asia, Asia Pacific Journal of Education 31(3): 229-248, 2011.

7. Wilkins S., Huisman J., Student Recruitment at International Branch Campuses: Can They Compete in the Global Market? J Stud Int Educ, 15(3), 299-316, 2011.

8. Collins F., Globalising higher education in and through urban spaces: Higher education projects, international student mobilities and trans-local connections in Seoul. Asia Pacific Viewpoint, 55, 242-257, 2014.

9. Yin M., Yeakey C. C., The policy implications of the global flow of tertiary students: a social network analysis, Oxford Review of Education, 45:1, 50-69, 2019.

10.UNESCO, Inbound internationally mobile students by continent of origin. 
http://data.uis.unesco.org/Index.aspx?queryid $=172,2020$

11.Teichler U., Student Mobility in Europe: The Informational Value of Official Statistics and Graduate Surveys. In: Curaj A., Scott P., Vlasceanu L., Wilson L. (eds) European Higher Education at the Crossroads. Springer, Dordrecht, 2012.

12. Maier V., Foreign Students Enrolled in the Medicine and Pharmacy Higher Education in Romania (1975-1989). Clujul Medical, 89(2), 2016.

13.Giambona F., Porcu M., Sulis I., Students Mobility: Assessing the Determinants of Attractiveness Across Competing Territorial Areas. Soc Indic Res 133, 1105-1132, 2017.

14.Kogan L. R., McConnell S. L., Gaining Acceptance into Veterinary School: A Review of Medical and Veterinary Admissions Policies and Practices. JVME 28 (3), 101-110, 2001.

15.Kinnison T., May S. A., Veterinary career ambitions correlate with gender and past experience, with current experience influencing curricular perspectives. Vet Rec, 172, 12, 31, 2013.

16. Nowacek G., Sachs L., Demographic variables in medical school admission. Acad Med 65: 140-144, 1990.

17.Lloyd J. W., Financial Dimensions of Veterinary Medical Education: An Economist's Perspective. JVME 40 (2), 85-93, 2013.

18.Lim C. C., Schulhofer-Wohl S., Kustritz M. V. R., Molgaard L. K., Lee D., Financial expectations of first-year veterinary students. JVME 247 (2), 196-203, 2015.

19.Brown JP, Silverman JD., The current and future market for veterinarians and veterinary medical services in the United States. $J$ Am Vet Med Assoc, 215:161-183, 1999.

20.Lofstedt J., Gender and veterinary medicine. Can Vet J, 44(7): 533-535, 2003.

21.Brown C., Hird D., Roth J., Wagner G., Jost C., Memon M., International Opportunities for Veterinary Medicine Students. JVME 29:4, 220-224, 2002.

22.Jost C., Memon M. A., Internationalizing Veterinary Education in the 21 st Century. JVME 29(4):216-9, 2002.

23.Tötemeyer S., Dobbs H., Rutland C. S., What Is it like to be an International Student at
BALIEVA G.

Veterinary School? Perception and Performance in First Year-A Case Study at a UK Veterinary School. JVME 39 (2), 180188, 2012.

24.Takuchev N., Vasilev K., Territorydetermined factors, influencing the enrolment of veterinary medicine students. BJVM 5 (1), 61-68, 2002

25.Bozhkov I., Study on the genesis of the factors for Europeanization of veterinary medicine in Bulgaria. Proceedings of the III Symposium on the History of Veterinary Medicine with international participation. St Zagora, 74, 2003.

26.Burmann M., Delius A., Student Mobility in Tertiary Education, ifo DICE Report, ISSN 2511-7823, ifo Institut - Leibniz, München, Vol. 15, Iss. 3, 48-50, 2017.

27. Andrews F.M. Veterinary school admissions in the United Kingdom: attracting students to veterinary careers to meet the expanding needs of the profession and of global society. Rev. sci. tech. Off. int. Epiz., 28 (2), 699-707, 2009.

28. Fontanini C., What are the motivations that steer women and men towards a career in veterinary medicine? In Koutselini. Mapping the gender equality : research and practices the national and international perspective, Nicosie, 117-127, 2011.

29. Ostovic M., Mikus T., Pavicic Z., Matkovic K., Mesic Z., Influence of socio-demographic and experiential factors on the attitudes of Croatian veterinary students towards farm animal welfare. Veterinarni Medicina, 62: 417-428, 2017.

30.Robbins J., Parsons R., Johnson A., Jorgensen M., Danielson J., Millman S., 321 Sociodemographic factors associated with attitudes towards animals among first-year veterinary students, Journal of Animal Science, 97, Suppl. 3, 5-6, 2019.

31.Amass S. F., Davis K. S., Salisbury S. K., Weisman J.L., Impact of gender and raceethnicity on reasons for pursuing a career in veterinary medicine and career aspirations. JAVMA 238 (11), 1435-1440, 2011.

32.Collins F. L., Regional Pathways: Transnational Imaginaries, Infrastructures and Implications of student mobility within Asia. Asian and Pacific Migration Journal, 22(4), 475-500, 2013. 
33.Collins F. L., Researching mobility and emplacement: examining transience and transnationality in international student lives. Area, 44, 296-304, 2012.

34. Hawthorne L., Indian Students and the Evolution of the Study-Migration Pathway in Australia. International Migration, 52(2), 319, 2014.

35.Held D. 'Regulating Globalization? The Reinvention of Politics', International Sociology, 15, 394-408, 2000.

36.Phillips M. W., Stahl C. W. International Trade in Higher Education Services in the Asia Pacific Region: Trends and Issues. ASIAN PAC MIGR J, 1O(2), 273-301, 2001.

37.UNESCO, Global Flow of Tertiary-Level Students $\quad-\quad$ Bulgaria. http://uis.unesco.org/en/uis-student-flow 2020

38.Radmard S., Exploration of the Factors Effecting Higher Education Demands of International Students in Turkish Universities. Journal of Higher Education and Science 7(1):67, 2017.

39. Weaver A. D., Demographic studies on final year veterinary students of nine European schools, Vet Rec 105(12):280-3, 1979.

40.Kostelnik K., Lotz F., Sötje L., Heuwieser W., Expectations of veterinary students and vocational reality. Tierärztliche Praxis. Ausgabe G, Grosstiere/Nutztiere, 38, 4, 209218, 2010.

41.Tomlin JL., Brodbelt DC., May SA., Influences on the decision to study veterinary medicine: variation with sex and background. Veterinary Record 166, 744-748, 2010

42. Sans P., Mounier L., Bénet J.J., Lijour B., The Motivations and Practice-Area Interests of First-Year French Veterinary Students (20052008). JVME 38(2), 199-207, 2011.

43. Heath TJ., Longitudinal study of veterinary students and veterinarians: effects of growing up on a farm with animals. Australian Veterinary Journal 85(7):296-9, 2007.
BALIEVA G.

44.Lazarova I., Volunteering as a tool for knowledge and skills gaining for veterinary students, BJVM 22, Suppl. 1, 185-189, 2019.

45. Bourke A., A Model of the Determinants Of international Trade in Higher Education. The Serv Ind J, 20, 110-318, 2000.

46. Orlova E. S., Zavodiyan I. S., Public opinion of foreign students about studying in Russian universities. Youth Science Forum Journal, Vol. 1, Issue 2, 112-122, 2020.

47.Ivy J., Higher education institution image: acorrespondence analysis approach. International Journal of Educational Management, 15:6, 276-282, 2001.

48. Välimaa J., Nationalisation, Localisation and Globalisation in Finnish Higher Education. Higher Education, 48, 27-54, 2004.

49. British Veterinary Association. BVA and London Vet Show Launch First Vet Careers Fair http://www.cabi.org/vetmedresource/news/219 68

50. British Veterinary Association. BVA Launches 1-2-1 Careers Service http://www.cabi.org/vetmedresource/news/226 19

51. British Veterinary Association. My Vet Future. https://www.vetrecordjobs.com/myvetfuture/

52. Cubillo J.M., Sánchez J., Cerviño J., International students' decision-making process, International Journal of Educational Management 20: 101-115, 2006.

53. Ward C., Masgoret A. M. The experience of international students in New Zealand: Report on the results of the National Survey. http://www.educationcounts.govt.nz/publicatio ns/international/14700, 2004.

54. Plotnikova I. V., Efremova O. N., Chechet D. M., Tchaikovskaya O. N., Bastida J. Wellbeing of Foreign Students Enrolled in Russian Universities: Trends in Development. The European Proceedings of Social \& Behavioural Sciences, eISSN: 2357-1330, 540-547, 2017

55.Prince J. Bruce, Gwinner Kevin, Andrus David M., Applicant Expectations and Decision Factors for Jobs and Careers in Food-Supply Veterinary Medicine. JVME 35(1), 14-19, 2008. 